\title{
Terrestrial and aquatic mammals of the Pantanal
}

\author{
Alho, CJR. ${ }^{\mathrm{a} *}$, Camargo, G. ${ }^{\mathrm{b} *}$ and Fischer, E. ${ }^{\mathrm{c} *}$ \\ aPrograma de Pós-graduação em Ambiente e Desenvolvimento Regional, Universidade Anhanguera - Uniderp, \\ CEP 79037-280, Campo Grande, MS, Brazil \\ 'Programa de Pós-graduação em Ecologia e Conservação, Universidade Federal de Mato Grosso do Sul - UFMS, \\ CEP 79070-900, Campo Grande, MS, Brazil \\ 'Departamento de Biologia, Universidade Federal de Mato Grosso do Sul - UFMS \\ CEP 79070-900, Campo Grande, MS, Brazil \\ *e-mail: alho@unb.br,gecamargo@gmail.com, eafischer@uol.com.br \\ Received October 14, 2010 - Accepted December 13, 2010 - Distributed April 30, 2011
}

(With 1 figure)

\begin{abstract}
Different works have registered the number of mammal species within the natural habitats of the Pantanal based on currently known records, with species richness ranging from 89 to 152 of annotated occurrences. Our present list sums 174 species. However, at least three factors have to be emphasised to deal with recorded numbers: 1) to establish the ecotone limit between the floodplain (which is the Pantanal) and its neighbouring domain like the Cerrado, besides the existence of maps recently produced; 2) the lack of intensive surveys, especially on small mammals, rodents and marsupials; and 3) the constant taxonomic revision on bats, rodents and marsupials. Some species are very abundant - for example the capybara Hydrochoerus hydrochaeris and the crab-eating fox Cerdocyon thous, and some are rare, and others are still intrinsically rare - for example, the bush dog Speothos venaticus. Abundance of species is assumed to reflect ecological resources of the habitat. Local diversity and number of individuals of wild rodents and marsupials also rely on the offering of ecological resources and behavioural specialisation to microhabitat components. A large number of species interact with the type of the vegetation of the habitat, by means of habitat selection through active patterns of ecological behaviour, resulting on dependency on arboreal and forested habitats of the Pantanal. In addition, mammals respond to seasonal shrinking-and-expansion of habitats due to flooding regime of the Pantanal. The highest number of species is observed during the dry season, when there is a considerable expansion of terrestrial habitats, mainly seasonally flooded grassland. Major threats to mammal species are the loss and alteration of habitats due to human intervention, mainly deforestation, unsustainable agricultural and cattle-ranching practices, which convert the natural vegetation into pastures. The Pantanal still harbours about a dozen of species officially listened as in danger.
\end{abstract}

Keywords: biodiversity, conservation, Pantanal habitats, mammal species, environmental threat.

\section{Mamíferos terrestres e aquáticos do Pantanal}

\section{Resumo}

Diversos trabalhos têm registrado o número de espécies de mamíferos nos diferentes hábitats naturais do Pantanal, com base nos registros do conhecimento corrente, com a riqueza de espécies variando de 89 a 152 ocorrências anotadas. Nossa lista atual soma 174 espécies. Contudo pelo menos três fatores devem ser enfatizados quando se lida com os números encontrados: 1) o limite exato do ecótono entre a bacia de inundação (que é o Pantanal) e os domínios vizinhos, como o Cerrado, apesar da existência de mapas recentes; 2) a falta de levantamentos intensivos, particularmente sobre pequenos mamíferos, roedores e marsupiais; e 3) a revisão taxonômica constante de morcegos, roedores e marsupiais. Algumas espécies são abundantes, como a capivara Hydrochoerus hydrochaeris, e o lobinho Cerdocyon thous, outras são raras e outras ainda são intrinsecamente raras, como o cachorro-vinagre Speothos venaticus. Assume-se que a abundância de espécies reflete os recursos ecológicos contidos nos hábitats. A diversidade local e o número de indivíduos de roedores silvestres e marsupiais também dependem da oferta ecológica de recursos e da especialização de comportamento para explorar componentes de micro-hábitats. Grande número de espécies interage com os tipos de vegetação do hábitat, por meio de seleção de hábitat com padrões ativos de comportamento ecológico, que resultam na dependência dos mamíferos de hábitats arbóreos e florestados do Pantanal. Além disso, os mamíferos respondem ao encolhimento e expansão dos hábitats devido à inundação sazonal do Pantanal, com abundância de espécies mais altas na estação seca, quando há considerável expansão de hábitats terrestres, principalmente campos inundáveis. As ameaças mais importantes para os mamíferos são a perda e alteração de hábitats devido à intervenção humana, particularmente o desmatamento, práticas de agricultura e pecuária insustentáveis, com conversão da vegetação natural em pastos. $\mathrm{O}$ Pantanal ainda abriga cerca de uma dúzia de espécies oficialmente ameaçadas de extinção.

Palavras-chave: biodiversidade, conservação, hábitats do Pantanal, espécies de mamíferos, ameaças ambientais. 


\section{Introduction}

The Pantanal wetland is largely known worldwide for its extraordinary wildlife, particularly the mammal species, which include jaguar, capybara, marsh deer, giant anteater, and many others, interacting in complex ecological communities. The Pantanal is composed of different landscapes constituted of habitat gradients which offer feeding and reproductive ecological niches, sustaining a high diversity of mammal species. The high heterogeneity of the Pantanal promotes the selection of different habitats by species which widely overlap in habitat use. The Pantanal community compositions are subject to an annual hydrological cycle which determines the ecosystem functioning and the high seasonal productivity, supporting a diverse and abundant fauna, including large and endangered mammal species (Alho et al., 1988; Alho, 2005a, 2008). These factors have influenced diversity throughout life history and nowadays also influence the presence of species competing for daily needs to survive and reproduce.

Several surveys on a different time scale have shown the great magnitude of the mammalian fauna of the Pantanal: on mammalian biomass (Schaller, 1983), on occurrence of species (Alho et al., 1988; Trolle, 2003), of a literature review (Coutinho et al., 1997; Rodrigues et al., 2002), on working group results (Marinho Filho, 2007), on responses to seasonal flooding (Mamede and Alho, 2006), on microhabitat use among small mammals (Lacher and Alho, 1989), on ecology (Alho, 2005a, 2008), and studies on single species such as capybaras (Alho et al., 1989; Alho, 2003), jaguar (Soisalo and Cavalcanti, 2006; Azevedo and Murray, 2007), march deer (Schaller and Vasconcelos, 1978; Mauro et al., 1998; Mourão et al., 2000), ocelot (Trolle and Kéry, 2005), and other studies.

Pantanal land use is altering natural habitats to accommodate human needs. The landscape has been modified by human intervention, mainly deforestation, unsustainable agricultural and cattle-ranching practices, which convert the natural vegetation into pastures (Alho et al., 1988; Alho, 2005a, 2008; Harris et al., 2005). Therefore, some natural habitats are in distress. The aim of this review is to present comprehensive ecological information that forms the magnitude foundation of the mammal species diversity in the Pantanal. We check out the mammal species already reported to occur in the Pantanal, and discuss the relevant patterns of habitat use and conservation strategies. Secondarily, the purpose here is to identify new lines of research (new perspectives, initiatives, analyses and interpretations) to motivate work to elucidate complex ecological phenomena, through environmental parameters, instead of simple lists of species occurrence.

\section{Methods}

We synthesise the literature in order to update recent developments on occurrence of wild mammal species in the Pantanal, as well as firmly relying on our two-decade work experience in the region, to identify diversity, abundance, habitat requirements, to understand mammalian dynamics. Our study also identifies major environmental threats dealing with a conservation agenda. Joining the available information, we approach comprehensive patterns of mammalian ecology, combining habitat features and species interactions in search of unifying trends for the species, populations and communities to the drastically seasonal habitats. The relevant literature on species occurrence, community composition, population densities, habitat preference, and interspecific relations of mammals in the Pantanal was surveyed.

The reviewing of records of Pantanal mammals was based on previous revisions and additional scientific literature and technical reports (Marinho-Filho and Sazima, 1998; Wilig et al., 2000; Oliveira et al., 2002; Rodrigues et al., 2002; Camargo and Fischer, 2005; Longo et al., 2007; Marinho-Filho, 2007; Carmignotto, 2004; Cáceres et al., 2008; Aragona and Marinho-Filho, 2009; Tomás et al., 2010). Species names follow Wilson and Reeder (2005) and Reis et al. (2006); classes of extinction threats follow the International Union for Conservation of Nature (IUCN) and the Livro Vermelho da Fauna Brasileira Ameaçada de Extinção (IBAMA) of the Ministério do Meio Ambiente (Brazilian Ministry of the Environment).

\section{Results and Discussion}

\subsection{Richness of Pantanal mammals}

The total number of mammal species that occur in the Pantanal wetland has been previously reported to vary between 89 and 152 (Alho et al., 2003; Alho, 2005a; Cáceres et al., 2008; Coutinho et al., 1997; Marinho Filho, 2007; Reis et al., 2006; Sabino and Prado, 2006; Tomás et al., 2010). According to the working group designated by the Ministry of Environment (Ministério do Meio Ambiente; see Marinho Filho, 2007) there are officially 132 species of mammals in the Brazilian Pantanal. Here we update this number to 170 mammal species in the Brazilian Pantanal, and to 174 species including the Pantanal floodplain in Northeastern Paraguay (Willig et al., 2000). The increased number of species reviewed here is partially related to constant progress in taxonomic revisions, especially with the support of cytogenetics to identify new species of small mammals (wild rodents and marsupials), and to the recently increase of surveys on bats - by far the richer order of mammals in the Pantanal (Figure 1) (Camargo and Fischer, 2005; Longo et al., 2007; Santos et al., 2010). Despite several mammal species being conspicuous in the Pantanal, like capybara - a symbol of the Pantanal - most of the mammal species are not easily recorded, as they present nocturnal and twilight habits. Thus, an increase in the number of mammal species is also expected as a result of improved sampling methods. Although additional species have been found over time, another difficulty to set the right number of mammal species is the problem in determining the exact limits of the Pantanal floodplain 


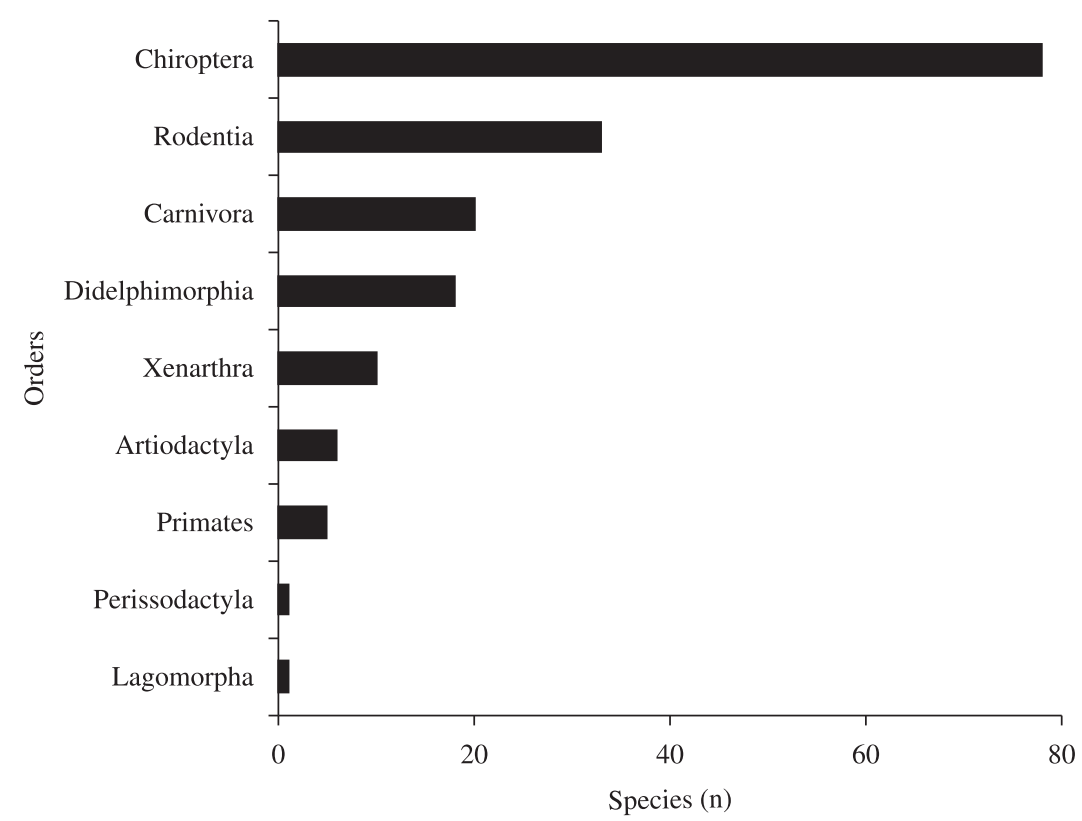

Figure 1. Species richness of nine orders of mammals which occur in the Pantanal floodplain.

relative to the surrounding domains of Cerrado, Amazonia, and Chaco.

The Pantanal is a savanna wetland (Alho, 2005a) and its biota is closer to that of Cerrado (195 mammal species), with some Amazonian and Chaco biogeographic influences. The flatland ( $80-150 \mathrm{~m}$ in altitude) has been considered the floodplain (Pantanal), and its surrounding Cerrado upland plateaus (200-1,200 $\mathrm{m}$ in altitude) is known as planalto. It helps to establish the Pantanal limits to some extent, but difficulties remain due to the complex maze of mosaic habitats, under different seasonal flooding regimes (Alho, 2008). There are official maps delimiting these bounders in the Paraguay river basin (ANA, 2004) as well as tentative delimitations of the Pantanal and its subregions based on criteria of flooding, relief, soil and vegetation type (Silva and Abdon, 1998). However, for mobile animals like wild mammals, these limits are unreasonable. Additionally, human activities have modified the landscape and so wild mammal occurrence and local distribution are changing (Alho, 2008). Unprecedented mammal species have been recorded in the uplands surrounding the Pantanal (e.g. Alho, 2000), and part of them might be expected to additionally occur in the floodplain.

\subsection{Habitats and resources}

The observed abundance of some species in the Pantanal habitats reveals that only a few species are common - for example the capybara Hydrochoerus hydrochaeris, the crab-eating fox Cerdocyon thous, and the flat-faced fruit-eating bat Artibeus planirostris - whereas some are rare or intrinsically rare - for example, the bush dog Speothos venaticus (Alho et al., 1988, 1989; Mamede and Alho, 2006; Alho, 2005a, 2008; Teixeira et al., 2009).
Species abundance is often assumed to be the result of availability of resources, for example, preferable habitats with a large offering of feeding and reproductive niches. This is the case of resources that affect the number of mammal species with a wide range of zoogeographical distribution like the capybara, marsh deer, crab-eating fox, but it does not apply to some species which are rare throughout all their distribution range, including the Pantanal, as is the case of the bush dog, which seems to be attached to greater ecological and behavioural specialisation, the strategy of which is to be intrinsically rare.

The patterns of habitat intergradations are even more complex in ecotone zones of broad contact between the Pantanal and Cerrado (Lacher and Alho, 2001). Habitat is an important factor in mammalian community structure. Vegetation types in different habitats influence mammal species. The physiognomic units of the Pantanal are characterised by their phytosociological and ecological arrangements, forming well-defined landscape units like seasonal flooding open fields, arboreal patches of savanna or capões de cerrado, semi-deciduous forest on upper grounds or cordilheiras, riverine and gallery forests, and others (Alho, 2005a; Silva et al., 1998). Therefore, the offering of different resources, particularly food and niches for reproduction, influences social systems of most populations of Pantanal mammals and determines local species richness, abundance, and competition.

Abundance of capybaras in the Pantanal varies seasonally, affected by changes in food abundance and available space due to annual flooding (Alho et al., 1989). Capybara's group sizes increases from the end of the rainy season to the dry season, when there are more young in the groups. During the dry season more capybaras are observed feeding on the 
pasture of the seasonal flooding open fields. In fact, higher densities of other mammal species occur during the dry season (August and September), when there is a considerable expansion of terrestrial habitats, mainly seasonally flooded grassland, due to the shrinking-and-expansion of habitats related to the flooding pulse (Mamede and Alho, 2006).

Capybara Hydrochoerus hydrochaeris and caiman Caiman yacare are the most common wild species killed by jaguars Panthera onca in the Pantanal (Azevedo and Murray, 2007), and both prey species are equally abundant in the region. Jaguars also consume a high variety of prey, including deer, peccary and others. It was estimated that the wild prey base was adequate to support the jaguar population in the study area. The study also concluded that spacing patterns in the local jaguar population were likely based on exclusion through territoriality rather than food limitation.

The total home range size area of five females and three male jaguars in the study area was $112.2 \mathrm{~km}^{2}$ (density of 0.07 adult resident jaguars per square kilometre). Home-range size was comparable between sexes; almost half of their home range areas was shared with conspecifics of the same sex, but little overlapping was observed at the core areas, suggesting that same-sex resident individuals established exclusive core areas (Azevedo and Murray, 2007). These results indicate that prey abundance was sufficiently abundant to influence patterns of exclusivity in the spatial distribution of resident jaguars and hence prey selection patterns. Although there is indication that prey availability influences jaguar populations in the Pantanal, spatial patterns seem to be influenced by a territorial system, governed by regions of exclusivity (home range and territory), rather than by prey abundance (Azevedo and Murray, 2007).

\subsection{Microhabitats and ecological resources}

Local diversity and number of individuals also rely on the offering of resources and behavioural specialisation to habitat components. On a small scale, specialised species are able to exploit the spatial and temporal variation of the habitat heterogeneity, including microhabitat components (Lacher and Alho, 1989; Alho, 2005b; Carmignotto and Monfort, 2006). In the Cerrado landscape, small mammal communities differ along a gradient of natural habitats (Alho, 2005b). Community differences appear to be a function of local mosaic factors as well as differences among river basins, between high plateau forested habitats and lowland valley forests, or between moister open areas with soft soil and abundant grass versus very dry and rocky microhabitats. For example, among small mammals, like marsupials and rodents, there are habitat generalists occurring in more than three types of habitat (pan-habitat species) and habitat specialists, showing a high degree of fidelity to habitat.

It is common to find small mammal species with a preference for arboreal or forested habitats or for open habitats within the same study area. In the semi-decidous forest habitats, surrounded by open savanna habitats, woodland-dwelling genera such as Cerradomys and Oligoryzomys occur within a few metres of transition zone-habitat dwellers such as Clyomys and Trichomys. The genus Oligoryzomys also occur in both open and forested habitats.

Microhabitat use among small mammals in the Pantanal shows that two genera of Cicretidae rodents - Oligoryzomys (with two species occurring in the Pantanal: O. chacoensis and $O$. microtis) and Cerradomys (C. subflavus) - are more generalised in their use of microhabitats than are two Echimyidae species - Clyomys laticeps and Trichomys pachyurus (referred to as T. apereoides in some publications, but recognised as a distinct species based on chromosomal differentiation; Bonvicino and Lacher, 2008). Oligoryzomys species are broad habitat generalist at the "Nhecolândia" sub-region of the Pantanal. Cerradomys subflavus patches of arboreal savanna, capão de cerrado. Both Clyomys and Trichomys were restricted to their transition microhabitat. Although both genera overlap in the same microhabitat, competition is avoided since Trichomys is scansorial while Clyomys is fossorial (Lacher and Alho, 1989). In general the transition between arboreal habitats and open areas are selected by Trichomys pachyurus (Carmignotto, 2004).

Studies carried out in habitats surrounding the Pantanal, on plateaus of Chapada dos Guimaraães, state of Mato Grosso, pointed out that the combination of vegetation type and substrate structured the community of 19 terrestrial species of small mammal into several smaller communities with little faunal overlap (Lacher and Alho, 2001). This study showed that most species were captured in only one or two of the qualitative habitat types. There were open habitat species completely absent from forest, and forest species that were captured only in forest habitats. Cluster analysis of 19 species studied confirmed the separation made by qualitative classification of habitats based on plant species composition and other habitat characteristics. The results for habitat associations of small mammal species determined by cluster analysis of soil and vegetation structural characteristics (independently of plant species composition) generated five fairly distinct clusters.

The gallery forest cluster grouped the same set of species that had previously been assigned to gallery forest (Neacomys spinosus, Hylaeamys megacephalus, Nectomys squamipes, Oecomys bicolor, Proechimys longicaudatus, and Caluromys philander), confirming the earlier analysis. The cluster analysis also grouped the six species that had previously been associated with wet field (Oligoryzomys microtis - occurring at the Cerrado-Amazonia contact zone, Oligoryzomys nigripes (= eliurus), Cerradomys subflavus species group, Necromys lasiurus, Monodelphis domestica, and Marmosa murina). The grouping of species was essentially the same whether it was done qualitatively by habitat type or by a quantitative analysis of structural aspects of the vegetation and substrate of the habitat (Lacher and Alho, 2001). Small mammals are more specialised regarding to habitat requirements, and so they are able to exploit different parts of the habitat mosaics of the Pantanal. 


\subsection{The dependence of forest habitats}

The Pantanal habitats support a number of living mammal species that interact with each other and with the type of the vegetation of the habitats. How these mammal species interact with the type of the vegetation is a result of habitat selection by means of active patterns of ecological behaviour. This interaction will then determine how a given species well uses the range of habitats to fulfill its daily need for food, space, shelter, social interactions, reproduction and other living requirements, as a result of habitat selection. The local presence of these required habitat needs, like forest areas, are essential to determine population and community parameters like species richness, abundance, reproductive potential and other.

In the Pantanal there are different mammal species that rely on forest or arboreal habitats, besides are frequently observed ranging in open landscape. If this condition is met, the species will typically show populations parameters like high densities within preferable habitats. Studies on capybaras of the Pantanal show that the use of habitats varies seasonally (Alho et al., 1989; Alho, 2005a, 2008). During the dry season, capybaras spend the night in the forest. In the early morning they leave the forest to graze on the grassland. During the rainy season, the capybaras also spend the night in the forest, but in the morning usually emerge and go directly to the water or to grazing areas. Use of aquatic and forest vegetation in their diet at that time increases significantly, since few grazing areas remain above water level. Group sizes ranged from 2 to 25 individuals, depending on the kind of preferable habitats. Each group occupied an area ranging from 33.67 to 196.04 ha. Home range of a group contained foraging open area, a patch of forest (usually a gallery forest or a patch of savanna, locally known as capão de cerrado) and water (river, corixo or baía). The densities in the most used habitats ranged from 0.01 to 0.69 capybara/ha. Each social group occupied a core area within its home range varying from 2.97 to 52.80 ha.

Many aspects of the behaviour and ecology of the capybara are affected by seasonal fluctuations in the amount of available food. Some preferred food items that are richer in protein tend to be more seasonal than poorer food items. There is a period of the year, from June until November, when the standing crop on lower areas susceptible to flooding is abundant and is consumed by capybaras. During the remainder of the year the presence of these food items is very scarce. Thus, the times of food abundance and scarcity are predicted by the flooding pattern. Capybara group size increases from the beginning (rainy season) to the middle of the year (dry season). During the floods the groups subdivide and are largely confined to the forest patches, while in the dry season more animals are observed feeding on the pasture of the grassland (Alho et al., 1989; Alho, 2005a, 2008; Mamede and Alho, 2006).

The major part of the habitat heterogeneity observed in an ecological community of the Pantanal is determined by vegetation, mainly the arboreal or forested habitat, that comprise a matrix of high complexity, forming different strata, occupied by mammal species. In general the fauna of the Pantanal and the surrounding Cerrado present strong dependency on habitat complexity (Alho et al., 2003; Alho, 2008).

Analyses using the 15 most abundant mammal species in the Pantanal habitats (considering macroniche characteristics) have pointed out that at least ten mammal species strongly rely on the presence of arboreal or forested habitats (Alho et al., 2003). This dependence on arboreal/forest habitats can be evaluated as a function of the characteristics of the macroniche used by each mammal species, considering the body size, its requirement of habitat quality, and its type of diet and locomotion. Five species (Alouatta caraya, Nasua nasua, Dasyprocta punctata, Cerdocyon thous and Mazama americana) are dependent on arboreal/forest habitats, and so intolerant to deforestation. Five other species (Myrmecophaga tridactyla, Ozotoceros bezoarticus, Hydrochoerus hidrochaeris and Tamandua tetradactyla) have shown moderate dependence on arboreal/forest habitats. Higher abundance of forested areas in a given study area in the Pantanal seems to favour the presence of jaguars (Azevedo and Murray, 2007).

\subsection{Semi-aquatic species}

Mammals adapted for aquatic life in the Pantanal, with webbed feet, a dense underfur, short legs, a long body and long tail, are two carnivore species belonging to the family Mustelidae, the giant otter Pteronura brasiliensis and the freshwater otter Lontra longicaudis. The capybara is a semi-aquatic largest rodent, a keystone species of the Pantanal. Another large mammal that frequently uses habitats with presence of water is the tapir Tapirus terrestris. The bush dog Speothos venaticus has a close association with water, presenting morphological adaptation for swimming, webbed feet.

Other mammal species with some association with water are marsupials, some confined to habitats of gallery forest and other kinds of arboreal habitats with close relation to water such as rivers and corixos: Marmosa murina; Micoureus constantiae and M. demerarae; Marmosops noctivagus and Chironectes minimus.

Giant otter Pteronura brasiliensisis has a long and flattened tail, adapted for swimming. The fur is thick and glossy. They are social animals, living in groups of 5-15 related individuals. They are highly vocal and their noise is easily recognised by riverine men in the Pantanal. The social group moves according to movement of seasonal water of the Pantanal, usually following school of fishes in movement. They pursue fish and hunt in groups. The giant otter is a semi-aquatic predator which relies mainly on fish, occurring in the Pantanal in habitats with slow moving waters (rivers, corixos and large permanent baías) presenting high productivity of fish. They are diurnal mammals and form cohesive social groups, moving in function of seasonal flooding. During the dry season the social groups occupy one stretch of the river, corixo or 
baía and actively scent mark the occupied territory also using communal latrines.

Different surveys have shown occurrence of giant otter in the Pantanal. The species is documented to occur (active burrows with recent tracks and latrines) along $324 \mathrm{~km}$ of the Aquidauana river, between the town of Aquidauana and the village of Passo da Lontra, in Mato Grosso do Sul state. The greater part of this river stretch is constituted by the Aquidauana River $(258 \mathrm{~km})$, and the remaining $82 \mathrm{~km}$ correspond to the Miranda River (Tomás et al., 2000).

A study conducted at Vermelho and Miranda rivers in the Pantanal concluded that time spent by giant otters marking varied between groups (Leuchtenberger and Mourão, 2009): the alpha males marked more frequently (62\% of marking events, 55 minutes) than the alpha females (17\% of marking events, 13.6 minutes). The study pointed out that scent-marking among giant otter individuals within the social group can play a relevant role in communication of social and sexual status and territorial defense.

The freshwater otter Lontra longicaudis has a semiaquatic habit since this species depends on the riverbanks, where they actively mark territories to rest and reproduce, and the water to search for food. Estimated density in some Pantanal areas is of one individual for each 2-3 km along the Negro river (Kruuk, 2006). They prefer clear running waters, protected by gallery forest, and river banks that can provide shelters. They prey primarily on fish, being observed alone or in small group, generally the female and its young.

\subsection{Threatened species}

Medium to large sized mammals (12 species), two bat and rodent species of the Pantanal are considered threatened, according to the Livro Vermelho da Fauna Brasileira Ameaçada de Extinção (Brazilian Red Book of the Fauna Threatened with Extinction) of the Ministério do Meio Ambiente (Brazilian Ministry of the Environment) based on documents published by IBAMA (Brazilian Institute of Environment and Renewable Natural Resources - Portaria $N^{o} .62$ in 1997), and by the Ministry (Instrução Normativa $N^{o} .3$ in 2003, and Instrução Normativa $N^{o} .5$ in 2004) (Table 1). Among bat species are Vampyrum spectrum and Chiroderma doriae. Phyllomys brasiliensis is the only rodent occurring in the Pantanal redlisted as endangered in both lists (MMA, 2008a,b; IUCN, 2011). Blastoceros dichotomus, Chrysocyon brachyurus, Leopardus pardalis, Leopardus tigrinus, Leopardus wiedii, Myrmecophaga tridactyla, Leopardus colocolo, Panthera onca, Priodontes maximus, Pteronura brasiliensis, Puma concolor, and Speothos venaticus are among medium-large sized mammals listed in the Brazilian Red Book (Table 1), as well in the IUCN Redlist, which some differences in the categories (Table 1).

The marsh deer, cervo-do-pantanal, Blastocerus dichotomus, is the largest Brazilian deer. Interdigital membranes, extended hooves, and relatively long limbs are adaptation features to flooding habitats (Tomás et al., 1997).
The threat status of this species is vulnerable, including MMA ranking as well as IUCN category. All vegetation communities in which marsh deer Blastocerus dichotomus have been observed (Tomás, 1993) are frequently flooded during the wet season (most habitats are formed by aquatic plants). The vegetation type most used by marsh deer is Andropogon grassland and other open areas are dominated by Pontederia, Scleria, Nymphaea, Eleocharis, Thalia, Axonopus, Oryza, Nymphoides and Luziola communities. Marsh deer select about 35 plant species, mainly aquatic plants. Pontederia cordata L. (including both flowers and leaves), Thalia geniculata L. (mainly flowers), Nymphaea spp. L., Aeschynomene sensitiva Sw., A. fluminensis Vell. Conc., Discolobium pulchellum Benth, Reussia spp. Endl., Leersia hexandra $\mathrm{Sw}$. and others are frequently eaten by marsh deer. Tomás (1993) provides a list of those plants.

Two canid species are in danger: the maned wolf and the bush dog. The maned wolf - lobo-guará- Chrysocyon brachyurus, inhabits the grasslands and scrub forest of the Pantanal. It is listed as vulnerable by MMA and near threatened by IUCN. Its population is experiencing a continuing decline due to ongoing habitat loss and degradation, road kills and other threats (Rodden et al., 2008). The bush dog or cachorro-vinagre Speothos venaticus is categorised as vulnerable. It is an intrinsically rare species although having a wide distribution range, it is nowhere abundant and occurs at very low densities.

Bush dogs are habitat generalist, showing some preference to areas near water. Survey on direct sightings and evidences of occurrence (feces, tracks, carcasses) recorded in a protected area of the Pantanal have shown a home-range size of $150 \mathrm{~km}^{2}$ occupied by a group of six bush dogs (Lima et al., 2009). It was estimated the presence of about five groups of bush dogs with sizes varying from two to five individuals, but about two was the average group size, although some isolated individuals were detected. This study identified the nine-banded armadillo Dasypus novemcinctus as the preferred prey of bush dogs. In forest habitats they create dens in burrows of old trees where the female nurses its young.

Threatened felid species of the Pantanal are: the ocelot or jaguatirica, Leopardus pardalis mitis, listed by MMA as vulnerable; the little spotted cat or gato-do-matopequeno, Leopardus tigrinus, under the threat category of vulnerable; the margay cat or gato-maracajá, Leopardus wiedii, listed as vulnerable; the Pampas cat or gato-palheiro, Leopardus colocolo, also vulnerable; the puma or suçuarana Puma concolor shows sympatric range with jaguar in the Pantanal (two subspecies are listed as vulnerable by MMA: P.c. capricornensis and P.c.greeni, both not occurring in the Pantanal); and the jaguar or onça, Panthera onca, categorised as vulnerable. Among felid species, Leopardus wiedii and Panthera onca are categorised as vulnerable by IUCN Red List.

These species occur within the Pantanal habitats, documented in different studies. Using capture-recapture analysis, Trolle and Kéry (2005), estimated Leopardus pardalis density in a study area of 0.112 individuals 
Table 1. List of 174 mammal species occurring in the Pantanal floodplain, ordered from the most to the least speciose groups, based on published records. Extinction threatening status by the International Union for Conservation of Nature (IUCN) and the Livro Vermelho da Fauna Brasileira Ameaçada de Extinção (MMA, 2008) is given.

\begin{tabular}{l}
\hline ORDER \\
$\begin{array}{l}\text { Family } \\
\text { Species }\end{array}$ \\
IUCN \\
IBAMA
\end{tabular}

\section{CHIROPTERA}

Phyllostomidae

Anoura caudifer (E. Geoffroy, 1818)

Anoura geoffroyi Gray, 1838

Artibeus cinereus (Gervais, 1856)

Artibeus fimbriatus Gray, 1838

Artibeus glaucus Thomas, 1893

Artibeus lituratus (Olfers, 1818)

Artibeus obscurus (Schinz, 1821)

Artibeus planirostris (Spix, 1823)

Carollia brevicauda (Schinz, 1821)

Carollia perspicillata (Linnaeus, 1758)

Chiroderma doriae O. Thomas, 1891

Chiroderma villosum Peters, 1860

Chrotopterus auritus (Peters, 1856)

Desmodus rotundus (E. Geoffroy, 1810)

Diaemus youngi (Jentink, 1893)

Diphylla ecaudata Spix, 1823

Glossophaga soricina (Pallas, 1766)

Glyphonycteris behnii (Peters, 1865) (= Micronycteris behnii)

Lonchorhina aurita Tomes, 1863

Lophostoma brasiliense Peters, 1866 (= Tonatia brasiliense)

Lophostoma silvicolum d'Orbigny, 1836 (= Tonatia silvicola)

Macrophyllum macrophyllum (Schinz, 1821)

Micronycteris megalotis (Gray, 1842)

Micronycteris minuta (Gervais, 1856)

Micronycteris sanborni Simmons, 1996

Mimon bennettii (Gray, 1838)

Mimon crenulatum (E. Geoffroy, 1803)

Phylloderma stenops Peters, 1865

Phyllostomus discolor Wagner, 1843

Phyllostomus elongatus (E. Geoffroy, 1810)

Phyllostomus hastatus (Pallas, 1767)

Platyrrhinus helleri (Peters, 1866)

Platyrrhinus lineatus (E. Geoffroy, 1810)

Pygoderma bilabiatum (Wagner, 1843)

Sturnira lilium (E. Geoffroy, 1810)

Tonatia bidens (Spix, 1823)

Trachops cirrhosus (Spix, 1823)

Uroderma bilobatum Peters, 1866

Uroderma magnirostrum Davis, 1868

Vampyressa pusilla (Wagner, 1843)

Vampyrodes caraccioli (Thomas, 1889)

Vampyrum spectrum (Linnaeus, 1758) 
Table 1. Continued...

ORDER

Family

IUCN IBAMA

Species

Cynomops abrasus (Temminck, 1827) (= Molossops abrasus)

Cynomops planirostris (Peters, 1865) (= Molossops planirostris)

Eumops auripendulus (Shaw, 1800)

Eumops bonariensis (Peters, 1874)

Eumops glaucinus (Wagner, 1843)

Eumops patagonicus Thomas, 1924

Eumops perotis (Schinz, 1821)

Molossops temminckii (Burmeister, 1854)

Molossus currentium (Thomas, 1901) $(=$ M. bondae)

Molossus molossus (Pallas, 1766)

Molossus pretiosus Miller, 1902

Molossus rufus E. Geoffroy, 1805 (= M. ater)

Nyctinomops aurispinosus (Peale, 1848)

Nyctinomops laticaudatus (E. Geoffroy, 1805)

Nyctinomops macrotis (Gray, 1840)

Promops centralis Thomas, 1915

Promops nasutus (Spix, 1823)

Vespertilionidae

Eptesicus brasiliensis (Desmarest, 1819)

Eptesicus furinalis (d'Orbigny, 1847)

Histiotus velatus (I. Geoffroy, 1824)

Lasiurus borealis (Muller, 1776)

Lasiurus cinereus (Beauvois, 1796)

Lasiurus ega (Gervais, 1856)

Myotis albescens (E. Geoffroy, 1806)

Myotis nigricans (Schinz, 1821)

Myotis riparius Handley, 1960

Myotis simus Thomas, 1901

Emballonuridae

Centronycteris maximiliani (Fischer, 1829)

Peropteryx kappleri Peters, 1867

Peropteryx macrotis (Wagner, 1843)

Rhynchonycteris naso (Wied-Neuwied, 1820)

Saccopteryx bilineata (Temminck, 1838)

Saccopteryx leptura (Schreber, 1774)

Mormoopidae

Pteronotus gymnonotus Natterer, 1843

Pteronotus parnellii (Gray, 1843)

Pteronotus personatus (Wagner, 1843)

Noctilionidae

Noctilio albiventris Desmarest, 1818

Noctilio leporinus (Linnaeus, 1758)

\section{RODENTIA}

Cricetidae 
Table 1. Continued...

\section{ORDER}

Family

IUCN

IBAMA

Species

Akodon toba Thomas, 1921

Akodon varius Thomas, 1902

Calomys callosus (Rengger, 1830)

Cerradomys scotti Langguth \& Bonvicino, 2002 (= Oryzomys scotti)

Cerradomys subflavus (Wagner, 1842) (= Oryzomys subflavus)

Holochilus brasiliensis (Desmarest, 1819)

Holochilus sciureus Wagner, 1842

Hylaeamys megacephalus (Fischer, 1814) (= Oryzomys megacephalus, O. capito)

Kunsia tomentosus (Lichtenstein, 1830)

Necromys lasiurus (Lund, 1841) (= Bolomys lasiurus)

Nectomys squamipes (Brants, 1827)

Oecomys bicolor (Thomas, 1860)

Oecomys concolor (Wagner, 1845) (= Oryzomys concolor)

Oecomys mamorae (Thomas, 1906)

Oecomys roberti (Thomas, 1904)

Oligoryzomys chacoensis (Myers \& Carleton, 1981)

Oligoryzomys fornesi (Massoia, 1973)

Oligoryzomys microtis (Allen, 1916)

Oligoryzomys nigripes (Olfers, 1818)

Echimyidae

Clyomys laticeps (Thomas, 1909)

Phyllomys brasiliensis Lund, 1839 (= Echimys brasiliensis)

En

En

Proechimys longicaudatus (Rengger, 1830)

Thrichomys apereoides (Lund, 1839)

Thrichomys pachyurus (Wagner, 1845)

Caviidae

Cavia aperea Erxleben, 1777

Galea musteloides Meyen, 1832

Hydrochoerus hydrochaeris (Linnaeus, 1766)

Dasyproctidae

Dasyprocta azarae Lichtenstein, 1823

Dasyprocta punctata Gray, 1842

Sciuridae

Guerlinguetus ignitus (Gray, 1867) (= Sciurus ignitus)

Urosciurus spadiceus Olfers, 1818 (= Sciurus spadiceus)

Cuniculidae

Cuniculus paca (Linnaeus, 1766) (= Agouti paca)

Erethizontidae

Coendou prehensilis (Linnaeus, 1758)

\section{CARNIVORA}

Felidae

Leopardus colocolo (Molina, 1782) (= Oncifelis colocolo, L. braccatus)

Leopardus geoffroyi (d 'Orbigny \& Gervais, 1844) (= Oncifelis geoffroyi) 
Table 1. Continued...

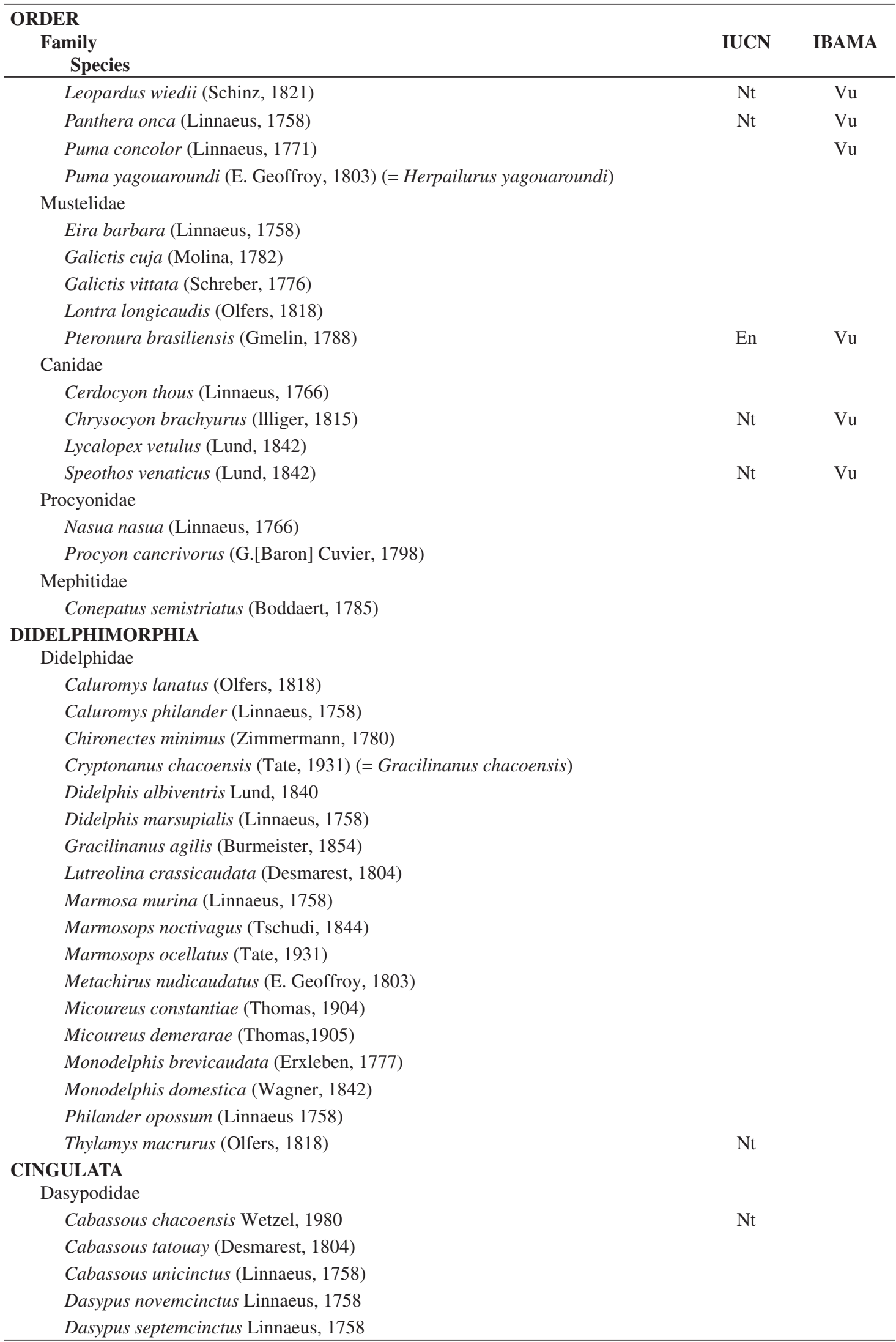


Table 1. Continued...

\begin{tabular}{|c|c|c|}
\hline $\begin{array}{l}\text { ORDER } \\
\text { Family } \\
\text { Species }\end{array}$ & IUCN & IBAMA \\
\hline \multicolumn{3}{|l|}{ Euphractus sexcinctus (Linnaeus, 1758) } \\
\hline Priodontes maximus (Kerr, 1792) & $\mathrm{Vu}$ & $\mathrm{Vu}$ \\
\hline Tolypeutes matacus (Desmarest, 1804) & $\mathrm{Nt}$ & \\
\hline \multicolumn{3}{|l|}{$\begin{array}{l}\text { ARTIODACTYLA } \\
\text { Cervidae }\end{array}$} \\
\hline Blastocerus dichotomus (Illiger, 1815) & $\mathrm{Vu}$ & $\mathrm{Vu}$ \\
\hline \multicolumn{3}{|l|}{ Mazama americana (Erxleben, 1777) } \\
\hline \multicolumn{3}{|c|}{ Mazama gouazoubira (Fischer, 1814) (= M. gouazoupira) } \\
\hline Ozotoceros bezoarticus (Linnaeus, 1758) & $\mathrm{Nt}$ & \\
\hline \multicolumn{3}{|l|}{ Tayassuidae } \\
\hline \multicolumn{3}{|l|}{ Pecari tajacu (Linnaeus, 1758) } \\
\hline Tayassu pecari (Link, 1795) & $\mathrm{Nt}$ & \\
\hline \multicolumn{3}{|l|}{$\begin{array}{l}\text { PRIMATES } \\
\text { Cebidae }\end{array}$} \\
\hline \multicolumn{3}{|l|}{ Cebus apella (Linnaeus, 1758) $(=$ C. cay) } \\
\hline \multicolumn{3}{|c|}{ Mico melanurus (E. Geoffroy in Humboldt, 1812) (= Callithrix melanura) } \\
\hline \multicolumn{3}{|l|}{ Aotidae } \\
\hline \multicolumn{3}{|l|}{ Aotus azarae (Humboldt, 1811) } \\
\hline \multicolumn{3}{|l|}{ Atelidae } \\
\hline \multicolumn{3}{|l|}{ Alouatta caraya (Humboldt, 1812) } \\
\hline \multicolumn{3}{|l|}{ Pitheciidae } \\
\hline \multicolumn{3}{|l|}{ Callicebus donacophilus (d'Orbigny, 1836) } \\
\hline \multicolumn{3}{|l|}{$\begin{array}{l}\text { PILOSA } \\
\quad \text { Myrmecophagidae }\end{array}$} \\
\hline Myrmecophaga tridactyla Linnaeus, 1758 & $\mathrm{Nt}$ & $\mathrm{Vu}$ \\
\hline \multicolumn{3}{|l|}{ Tamandua tetradactyla (Linnaeus, 1758) } \\
\hline \multicolumn{3}{|l|}{$\begin{array}{l}\text { LAGOMORPHA } \\
\text { Leporidae }\end{array}$} \\
\hline \multicolumn{3}{|l|}{ Sylvilagus brasiliensis (Linnaeus, 1758) } \\
\hline \multicolumn{3}{|l|}{$\begin{array}{l}\text { PERISSODACTYLA } \\
\text { Tapiridae }\end{array}$} \\
\hline Tapirus terrestris Linnaeus, 1758 & $\mathrm{Vu}$ & \\
\hline
\end{tabular}

per $\mathrm{km}^{2}$. Soisalo and Cavalcanti (2006), studying jaguars in the Pantanal, found densities ranging from 6.6 to 11.7 jaguars $/ 100 \mathrm{~km}^{2}$, depending on the survey method employed. They successfully tested the suitability of camera-trap capture-recapture sampling methods combined with telemetry technology for monitoring the status of jaguars in an open wet grassland habitat of the Pantanal. In a study area of the Pantanal, a jaguar density ranging from 6.5 to 6.7 individuals per $100 \mathrm{~km}^{2}$ was estimated (Trolle and Kéry, 2005).

The giant-armadillo - tatu-canastra-Priodontes maximus is the largest nocturnal and fossorial living armadillo, occurring in the Pantanal. Its threatened category is vulnerable in the MMA and IUCN lists. The semi-aquatic giant otter or ariranha, Pteronura brasiliensis, is also categorised as vulnerable by MMA, and as endangered by IUCN (see 3.4 Semi-aquatic species).

In addition to Brazilian legislation on endangered wildlife, there are international organisations dealing with trade of wild species CITES (1979) (Convention on International Trade in Endangered Species of Flora and Fauna- Convenção sobre o Comércio Internacional das Espécies da Flora e da Fauna Selvagens em Perigo de Extinção) which Brazil has been a part of since 1975Dec. $n^{\circ} 76.623 / 75$; conservation and Red List or Red Data List on endangered species - IUCN (2011) (International Union for Conservention of Nature - União Internacional para Conservação da Natureza e dos Recursos Naturais); 
knowledge, conservation and sustainable use of biodiversity (Convention on Biological Diversity - Convenção sobre Diversidade Biológica) (CBD, 1992) and others.

\subsection{Response of mammals to seasonal flooding}

Mammals respond to seasonal shrinking-and-expansion of habitats due to flooding regime of the Pantanal with highest abundance of species observed during the dry season (August and September), when there is a considerable expansion of terrestrial habitats, mainly seasonally flooded grassland (Mamede and Alho, 2006). Animal abundance (in terms of observed individual frequencies) varied during the dry and wet seasons and the seasonally flooded grassland was the most utilised habitat by mammals in the dry season.

Recurrent shallow flooding occupies $80 \%$ of the Pantanal; during the dry season flooded areas dry up. Fluctuating water levels, nutrients and wildlife form a dynamic ecosystem. A total of 36 species were observed in the field. The capybara Hydrochoerus hydrochaeris was the most frequent species, followed by the crab-eating-fox Cerdocyon thous and the marsh deer Blastocerus dichotomus (Mamede and Alho, 2006).

A study scanning multichannel microwave radiometres to reveal inundation patterns in the Pantanal showed maximum inundation occurring as early as February in the northern sub-regions and as late as June in the south, as a result of the delayed drainage of the region (Hamilton et al., 1996). An area of $131,000 \mathrm{~km}^{2}$ was inundated annually during nine years of observation, between 1979 and 1987. An average area of $53,000 \mathrm{~km}^{2}$ is inundated annually and monthly estimates of the total area inundated range from 11,000 to $110,000 \mathrm{~km}^{2}$.

There is observed evidence that seasonal habitat availability of the Pantanal influences population parameters of mammal species. By comparing observed frequencies of animals in the survey transects, a frequency analysis was applied to check the difference of habitat utilisation by the species showed statistically significant differences among the observed habitats - seasonally flooded grassland, patches of Cerrado, gallery forest and mesophytic forest and the seasonally flooded grassland was the most utilised habitat by the species, followed by the mesophytic forest and gallery forest. Thus, there is a significant association of species utilisation and type of available seasonal habitat (Mamede and Alho, 2006). Additionally, the distribution of the marsh deer in the Pantanal varies as a function of seasonal floods (Tomás et al., 2001).

\subsection{Concluding remarks: conservation implications}

The terrestrial and aquatic habitats used by the Pantanal mammals have been selected over an evolutionary scale by the rhythm of annual flooding in the wet season and retraction of the water to river valleys in the dry season. Among more than 170 mammals species (see Table 1) distributed in the Pantanal's habitats, there are 14 species officially listed as in danger. In natural habitats of the Pantanal, the interacting effects of multiple ecological processes determine the health of mammalian community structure and function. If any one or more of the conditions needed for a healthy mammalian community is missing, for example, absence of an arboreal or forested area due to conversion of local vegetation into pasture, it can cause a chain reaction affecting mammalian population parameters, community structure and behavioural ecology for feeding and reproductive niches. Human activities are increasing the vulnerability of the natural habitats of the Pantanal. Changes brought about by people have caused habitat loss and alteration, more erosion and sedimentation, pollution, unusual flooding and droughts.

Large-scale habitat disturbances, such as the use of fire and the conversion of natural vegetation into pasture or soybean plantations, have the potential to alter population parameters, community structure, use of space and other ecological requirements of mammal assemblages. Patches of cerrado (capões de cerrado) and cerradão on cordilheiras, for example, are rapidly disappearing as natural vegetation is converted into agricultural land or pastures for cattle ranching. Such environmental alterations can damage mammal habitat specialists and benefit pan-habitat species, changing community composition associated with pristine habitat gradients in the Pantanal landscape.

Although the Pantanal is rich in wildlife diversity and its habitats are still in good conservation status, about $95 \%$ of its area is still privately owned, with livestock being the main economic activity. However, in addition to increasing habitat loss and alteration due to deforestation, illegal hunting, overfishing, pollution like sewage from urban areas, erosion with sedimentation of river beds, and control of jaguars related to livestock activity are significant signs of human occupation, bringing wildlife and humans into direct conflict.

Acknowledgements - Cleber Alho has conducted research in the Pantanal for over two decades and statements provided here reflect this field experience. Celina Alho helped elaborating the manuscript. We thank Susan Casement for valuable language revision and comments. Financial support to G. Camargo was provided by CAPES and to E. Fischer by CNPq.

\section{References}

Agência Nacional de Águas - ANA, 2004. Strategic action program for the integrated management of the Pantanal and the Upper Paraguay River Basin. Brasília, DF: ANA/GEF/PNUMA/ OEA. 315 p.

ALHO, CJR., coord., 2000. Fauna silvestre da região do rio Manso - MT. Brasília: Ministério do Meio Ambiente. 268 p. Edições Ibama e Eletronorte.

-, 2003. Capybaras (entry of an encyclopedia). In KLEIMAN, DG., GEIST, V., HUTCHINS, M. and MCDADE, MC., Org. Grzimek's Animal Life Encyclopedia - Mammals V. Farmington Hills, Michigan: Gale Group. vol. 16, p. 401-406.

-, 2005a. The Pantanal. In FRASER, LH. and KEDDY, PA., Org. The World's Largest Wetlands - Ecology and Conservation. New York, USA: Cambridge University Press. p. 203-271. 
-, 2005b. Intergradation of habitats of non-volant small mammals in the patchy Cerrado landscape. Arquivos do Museu Nacional do Rio de Janeiro, vol. 63, p. 41-48.

-, 2008. Biodiversity of the Pantanal: response to seasonal flooding regime ant to environmental degradation. Revista Brasileira de Biologia = Brazilian. Journal of Biology, vol. 68, no. 4, p. 957-966. Suppl.

ALHO, CJR., CAMPOS, ZMS. and GONÇALVES, HC., 1989. Ecology, Social Behavior, and Management of the Capybara (Hydrochaeris hydrochoeris) in the Pantanal of Brazil. In REDFORD, KH. And EISENBERG, JF. Advances in Neotropical Mammalogy. Gainesville: Sandhill Crane Press, University of Florida. p. 163-194.

ALHO, CJR., LACHER Jr., TE., CAMPOS, JMS. and GONÇALVES, HC., 1988. Mamíferos da Fazenda Nhumirim, sub-região de Nhecolândia, Pantanal do Mato Grosso do Sul: Levantamento preliminar de espécies. Revista Brasileira de Biologia $=$ Brazilian Journal of Biology, vol. 48, no. 2, p. 213-225.

ALHO, CJR., STRUSSMANN, C., VOLPE, M., SONODA, F., MARQUES, AAB., SCHNEIDER, M., SANTOS-JUNIOR, TS. and MARQUES, SR., 2003. Conservação da Biodiversidade da Bacia do Alto Paraguai. Campo Grande - MS: Ed. UNIDERP. 466 p.

ARAGONA, M. and MARINHO-FILHO, J., 2009. História natural e biologia reprodutiva de marsupiais no Pantanal, Mato Grosso, Brasil. Zoologia, vol. 26, no. 2, p. 220-230.

AZEVEDO, FCC. and MURRAY, DL., 2007. Spatial organization and food habits of jaguars (Panthera onca) in a floodplain forest. Biological Conservation, vol. 137, p. 391-402.

BONVICINO, C. and LACHER, T., 2008. Thrichomys pachyurus. In IUCN 2009. IUCN Red List of Threatened Species. Version 2009.2. Available from: <www.iucnredlist.org $>$. Access in: 10 mar. 2010.

CÁCERES, NC., CARMIGNOTTO, AP., FISCHER, E. and SANTOS, CF., 2008. Mammals from Mato Grosso do Sul, Brazil. Check List, vol. 4, no. 3, p. 321-335.

CAMARGO, G. and FISCHER, E., 2005. Primeiro registro do morcego Mimon crenulatum (Phyllostomidae) no Pantanal, sudoeste do Brasil. Biota Neotropica, vol. 5, no. 1. Available from: <http://www.biotaneotropica.org.br/v5n1/pt/abstract?shortcommunication+ BN00705012005>

CARMIGNOTTO, AP., 2004. Pequenos mamíferos terrestres do bioma Cerrado: padrões faunísticos locais e regionais. São Paulo: Universidade São Paulo. 404 p. Doctoral thesis.

CARMIGNOTTO, AP. and MONFORT, T., 2006. Taxonomy and distribution of the Brazilian species of Thylamys (Didelphimorphia: Didelphidae). Mammalia, vol. 70, p. 126-144.

Convention on Biological Diversity - CBD, 1992. The Convention. Available from: <http://www.cbd.int/>.

Convention on International Trade in Endangered Species of Flora and Fauna - CITES, 1979. Text of the Convention. Available from: <http://www.cites.org/eng/disc/text.shtml>.

COUTINHO, ME., CAMPOS, ZMS., MOURÃO, GM. and MAURO, RA., 1997. Aspectos ecológicos dos vertebrados terrestres e semi-aquáticos no Pantanal. In Brasil. Ministério do Meio Ambiente, dos Recursos Hídricos e da Amazônia Legal. Plano de conservação da Bacia do Alto Paraguai (Pantanal) - PCBAP: diagnóstico dos meios físicos e bióticos: meio biótico. Brasília. vol. 2, no. 3, p. 183-322.
HAMILTON, SK., SIPPEL, SJ. and MELACK, JM., 1996. Inundation patterns in the Pantanal wetland of South America determined from passive microwave remote sensing. Archives of Hydrobiology, vol. 137, p. 1-23.

HARRIS, MB., TOMÁS, WM., MOURÃO, G., SILVA, CJ., GUIMARÃES, E., SONODA, F. and FACHIN, E., 2005. Safeguarding the Pantanal Wetlands: threats and conservation iniciatives. Conservation Biology, vol. 19, no. 3, p. 714-720.

International Union for Conservation of Nature - IUCN, 2011 Redlist. Available from: <http://www.iucn.org/about/work/ programmes/species/red_list/>.

KRUUK, H., 2006. Otter: ecology, behaviour and conservation. N.Y.: Oxford University Press, 261 p.

LACHER Jr., TE. and ALHO, CJR., 1989. Microhabitat use among small mammals in the Brazilian Pantanal. Journal of Mammalogy, vol. 70, no. 2, p. 396-401.

-, 2001. Terrestrial small mammal richness and habitat associations in an Amazon forest-Cerrado contact zone. Biotropica, Storrs, vol. 33 , no. 1, p. 171-181.

LEUCHTENBERGER, C. and MOURÃO, G., 2009. Scent-Marking of Giant Otter in the Southern Pantanal, Brazil. Ethology, vol. 115 , no. 3 , p. 210-216.

LIMA, ES., JORGE, RSP., DALPONTE, JC., 2009. Habitat use and diet of bush dogs, Speothos venaticus, in the Northern Pantanal, Mato Grosso, Brazil. Mammalia, vol. 73, no. 1, p. 13-19.

LONGO, JM., FISCHER, E., CAMARGO, G. and SANTOS, CF., 2007. Occurrence of Vampyressa pusilla Chiroptera, Phyllostomidae) in Southern Pantanal. Biota Neotropica, vol. 7, no. 3. Availabre from: <http://www.biotaneotropica.org.br/v7n3/ pt/abstract?short-communication+bn02407032007>.

MAMEDE, SB. and ALHO, CJR., 2006. Response of wild mammals to seasonal shrinking-and-expansion of habitats due to flooding regime of the Pantanal, Brazil. Revista Brasileira de Biologia = Brazilian Journal of Biology, vol. 66, no. 4, p. 991-998.

MARINHO FILHO, J., Org., 2007. Mastofauna do Cerrado e Pantanal - diversidade e conservação. In: Cerrado e Pantanal áreas e ações prioritárias para conservação da biodiversidade. Ministério do Meio Ambiente, Brasília. p. 300-321. Série Biodiversidade, no. 17.

MARINHO-FILHO, J. and SAZIMA, I., 1998. Brazilian bats and conservation biology: a first survey. In KUNZ, TH. and RACEY, PA., Ed. Bat biology and conservation. Washington D.C.: Smithsonisn Institution Press. p. 282-294.

MAURO, RA., MOURÃO, GM., COUTINHO, ME., SILVA, MP. and MAGNUSSON, WE., 1998. Abundance and distribution of marsh deer Blastocerus dichotomus (Artiodactyla: Cervidae) in the Pantanal, Brazil. Revista de Ecología Latinoamericana, vol. 5, no. 1-2, p. 13-20.

Ministério do Meio Ambiente - MMA, 2008a. Livro vermelho da fauna brasileira ameaçada de extinção. Brasília, DF. vol. 1, 511 p. Series Biodiversidade, vol. 19.

-, 2008b. Livro vermelho da fauna brasileira ameaçada de extinção. Brasília, DF. vol. 2, 907 p. Series Biodiversidade, vol. 19.

MOURÃO, G., COUTINHO, M., MAURO, R., CAMPOS, Z., TOMAS, W. and MAGNUSSON, W., 2000. Aerial surveys of caiman, marsh deer and pampas deer in the Pantanal Wetland of Brazil. Biological Conservation, vol. 92, p. 175-183. 
OLIVEIRA, JA., PESSÔA, LM., OLIVEIRA, LFB., ESCARLATE, F., CARAMASCHI, FP., LAZAR, A. and CORDEIRO, JLP., 2002. Mamíferos da RPPN Sesc Pantanal. In Conhecendo o Pantanal. Várzea Grande, MT, Brasil. p. 33-38. Divulgação de Pesquisa, no. 1.

REIS, NR., PERACCHI, AL., PEDRO, WA. and LIMA, IP., Ed., 2006. Mamíferos do Brasil. Londrina, PR, Brasil: Biblioteca Central da Universidade Estadual de Londrina. 437 p.

RODDEN, M., RODRIGUES, F. and BESTELMEYER, S., 2008. Chrysocyon brachyurus. In IUCN 2010. IUCN Red List of Threatened Species. Version 2010.1. Available from: $<w w w$.iucnredlist.org $>$. Access in: 13 mar. 2010.

RODRIGUES, FHG., MEDRI, IM., TOMÁS, WM. and MOURÃO, GM., 2002. Revisão do conhecimento sobre ocorrência e distribuição de Mamíferos do Pantanal. Embrapa Pantanal. 41 p. Documentos, no. 38 .

SABINO, J. and PRADO, PI., 2006. Síntese do conhecimento da diversidade biológica de vertebrados do Brasil. In: LEVINSOHN, T., Org. Avaliação do estado do conhecimento da diversidade brasileira. Brasília, DF: Ministério do Meio Ambiente. vol. 2, p. $55-143$.

SANTOS, CF., NOGUEIRA, M., CUNHA, N., CARVALHO, LF, and FISCHER, E., 2010. Southernmost record of the Sanborn's big-eared bat, Micronycteris sanborni (Chiroptera, Phyllostomidae). Mammalia, vol. 74, p. 457-460.

SCHALLER, GB., 1983. Mammals and their biomass on a Brazilian ranch. Arquivos de Zoologia, vol. 31, no. 1, p. 1-36.

SCHALLER, GB. and VASCONCELOS, JMC., 1978. A marsh deer census in Brazil. Orix, vol. 14, p. 345-351.

SILVA, JSV. and ABDON, MM., 1998. Delimitação do Pantanal Brasileiro e suas Sub-regiões. Pesquisa Agropecuária Brasileira, vol. 33, no. especial, p. 1703-1711.

SILVA, JSV., ABDON, MM., BOOK, A. and SILVA, MP., 1998. Fitofisionomias dominantes em parte das sub-regiões do Nabileque e Miranda, sul do Pantanal. Pesquisa Agropecuária Brasileira, vol. 33, no. especial, p. 1713-1720.

SOISALO, MK. and CAVALCANTI, SMC., 2006. Estimating the density of a jaguar population in the Brazilian Pantanal using camera-traps and capture-recapture sampling in combination with GPS radio-telemetry. Biological Conservation, vol. 129, p. 487-496.
TEIXEIRA, RC., CORREA, CE. and FISCHER, E., 2009. Frugivory by Artibeus jamaicensis (Phyllostomidae) bats in the Pantanal, Brazil. Studies on Neotropical Fauna and Environment, vol. 44, no. 1, p. 7-15.

TOMÁS, WM., 1993. Status and Ecology of a Marsh Deer (Blastocerus dichotomus) population in southern Pantanal, Brazil. Brasília. WWF-Brasil. Unpublished report.

TOMÁS, WM., BECCACECI, MD. and PINDER, L., 1997. Cervo-do-Pantanal. In DUARTE, JMB., Ed. Biologia e conservação de cervídeos sul-americanos: Blastocerus, Ozotoceros e Mazama. Jaboticabal, SP, Brasil: FUNEP. p. 24-38.

TOMÁS, WM., BORGES, PAL., ROCHA, HJF., SÁ-FILHO, R., KUTCHENSKI-JÚNIOR, F., and UDRY, TV., 2000. Potencial dos rios Aquidauana e Miranda, no Pantanal de Mato Grosso do Sul, para a conservação da ariranha (Pteronura brasiliensis). In III Simpósio sobre Recursos Naturais e Sócio-econômicos do Pantanal. Os Desafios do Novo Milênio. 27-30 nov. 2000, Corumbá, MS.

TOMÁS, WM., CÁCERES, NC., NUNES, AP., FISCHER, E., MOURÃO, GM. and CAMPOS, Z. 2010. Mammals in the Pantanal wetland, Brazil. In JUNK, WJ., SILVA, CJ., CUNHA, CN. and WANTZEN, KM., Org. The Pantanal: ecology, biodiversity and sustainable management of a large neotropical seasonal wetland. Sofia: Pensoft Publishers p. 127-141.

TOMÁS, WM., SALIS, SM., MOURÃO, GM. and SILVA, MP., 2001. Marsh deer (Blastocerus dichotomus) distribution as a function of floods in the Pantanal wetland, Brazil. Studies on Neotropical Fauna and Environment, vol. 36, no. 1, p. 9-13.

TROLLE, M., 2003. Mammal survey in Western Pantanal. Biodiversity and Conservation, vol. 12, p. 823-826.

TROLLE, M. and KÉRY, M., 2005. Camera-trap study of ocelot and other secretive mammals in the northern Pantanal. Mammalia, vol. 69 , no. $3-4$, p. $409-416$

WILLIG, MR., PRESLEY, SJ., OWEN, RD. and LOPEZGONZALEZ, C., 2000. Composition and structure of bat assemblages in Paraguay: A subtropical-temperate interface. Journal of Mammalogy, vol. 81, p. 386-401.

WILSON, DE. and REEDER, DM., Eds., 2005. Mammal species of the world. A taxonomic and geographic reference. $3^{\text {rd }}$ ed. Johns Hopkins University Press. 2142 p. 